\title{
Long-Term Treatment of Native LDL Induces Senescence of Cultured Human Endothelial Cells
}

\author{
Sung-Tack Oh, ${ }^{1}$ Hoon Park, ${ }^{1}$ Hyun Joong Yoon, ${ }^{2}$ and Sung Yeul Yang ${ }^{2}$ \\ ${ }^{1}$ Department of Obstetrics and Gynecology, Chonnam National University Medical School, 264 Seoyang-ro, Hwasun-eup, \\ Jeollanam-do 58128, Republic of Korea \\ ${ }^{2}$ Department of Biochemistry, Chonnam National University Medical School, 264 Seoyang-ro, Hwasun-eup, \\ Jeollanam-do 58128, Republic of Korea
}

Correspondence should be addressed to Sung Yeul Yang; syyang@jnu.ac.kr

Received 17 August 2016; Revised 23 November 2016; Accepted 28 December 2016; Published 19 January 2017

Academic Editor: Maria João Martins

Copyright (C) 2017 Sung-Tack Oh et al. This is an open access article distributed under the Creative Commons Attribution License, which permits unrestricted use, distribution, and reproduction in any medium, provided the original work is properly cited.

\begin{abstract}
The study aimed to evaluate whether the treatment of primary cultured human endothelial cells with native low-density lipoprotein (nLDL) could induce their senescence and to uncover some of the putative mechanisms involved. For this purpose, human umbilical vein endothelial cells (HUVECs) were subcultured and/or continuously cultured with nLDL $(0,2,5$, and $10 \mu \mathrm{g}$ protein/mL), for up to 9 days. The results indicated that nLDL inhibited the proliferation of HUVECs by arresting the cell cycle at G1 phase. The G1-arrested cells showed increase in cytosolic senescence-associated- $\beta$-galactosidase (SA- $\beta$-Gal) activity, a biomarker of cellular senescence. The causative factor of the cellular senescence was nLDL itself and not oxidized LDL (oxLDL), since blocking LDL receptor (LDLR) with the anti-LDLR antibody opposed the nLDL-induced increase of SA- $\beta$-Gal activity and decrease of cellular proliferation. In addition, nLDL-induced cellular senescence by inhibiting the phosphorylation of pRb (G1 arrest) via p53 as well as p16 signal transduction pathways. G1 phase arrest of the senescent cells was not overcome by nLDL removal from the culture medium. Moreover, the nLDL-treated cells produced reactive oxygen species (ROS) dose- and time-dependently. These results suggested, for the first time, that long-term treatment of nLDL could induce the premature senescence of endothelial cells.
\end{abstract}

\section{Introduction}

Aging is one of the main risk factors for cardiovascular diseases. Aging of blood vessels is associated with the development of endothelial dysfunction $[1,2]$ and atherosclerosis [3-5]. According to recent studies, vascular endothelial cells' senescence, that is, vascular aging, might be a fundamental cause for the development of cardiovascular diseases [610]. However, the molecular mechanisms of vascular aging remain unclear.

Cellular senescence is a stress response phenomenon that results in (a) a permanent secession from the cell cycle and (b) the appearance of distinct morphological and functional changes associated with impaired cellular homeostasis [6]. Cellular senescence can be classified into two types according to the presence or the absence of telomere shortening [11, 12]. Cellular senescence resulting from repeated cellular replication is called "replicative senescence" $[13,14]$. In this type of senescence, the progressive shortening of telomeres, by end-replication problems, and their eventual dysfunction are considered as fundamental mechanisms of senescence induction. Another type of cellular senescence results from acute senescence response to various stressful conditions, such as intracellular oxidative stress or persistent mitogenic stimulation. This second type of cellular senescence is known as "stress-induced premature senescence" and is not accompanied by telomere shortening [15-17]. Both types of cellular senescence can occur in living organisms and are associated with diseases and aging of individuals [18-20].

Oxidized low-density lipoprotein (oxLDL) can exert various unfavorable effects on vascular endothelial cells, such as the impairment of endothelial nitric oxide formation [21], induction of endothelial expression of adhesion molecules [22], induction of superoxide anion formation from the vascular tissue [23], and induction of apoptosis [24] and senescence [25] of endothelial cells. Although oxLDL plays 
an important role in cellular senescence, the oxLDL levels in the blood of healthy adults, measured by an ELISA assay with a specific antibody, are about $0.12 \sim 0.13 \mathrm{ng} / \mu \mathrm{g}$ LDL apolipoprotein $\mathrm{B}$, which is $<0.02 \%$ of total LDL $[26,27]$.

Actually, native LDL (nLDL), a LDL particle free of any modification induced by any agent within the blood, is hardly oxidized due to active circulating antioxidants; in addition, Kupffer cells and sinusoidal endothelial cells in the liver would rapidly remove the oxLDL already produced [28, 29]. Circulating nLDL is most probably oxidized within the vascular wall and diffuses into the blood [30, 31]. These data are suggestive of a negligible contribution of oxLDL to the in vivo development of atherosclerosis and cellular senescence in the absence of pathological conditions, such as hyperlipidemia or diabetes mellitus.

Native LDL could potentially promote the recruitment of monocytes [32] and expression of cell adhesion molecules $[33,34]$ by disturbing the lipid dynamics of the endothelial cell membrane. These effects of nLDL on vascular endothelial cells could lead to the development of atherosclerosis [35]. However, it is unclear whether nLDL could contribute to the development of cellular senescence.

Native LDL-induced endothelial dysfunction and expression of cell adhesion molecules in endothelial cells match the phenotypes of vascular aging, that is, endothelial cell senescence $[18,36]$. Hence, most likely, nLDL could induce the senescence of endothelial cells. Thus, we determined whether nLDL could induce the senescence of primary cultured human endothelial cells (HUVECs).

\section{Materials and Methods}

2.1. Materials. HUVECs (catalog number MC1133) was purchased from Modern Cell \& Tissue Technology (Seoul, Korea) and microvascular endothelial cell medium-2 (EGM2) was purchased from Cambrex (East Rutherford, NJ, USA). RIPA lysis buffer and protease inhibitor cocktail were purchased from Santa Cruz Biotechnology (Santa Cruz, CA, USA). West-ZOL ${ }^{\circledR}$ (plus) was purchased from iNtRON Biotechnology (Seongnam, Korea). EZ-Cytox ${ }^{\circledR}$ cell viability assay kit was purchased from Daeil Lab Service (Seoul, Korea). X-Gal (5-bromo-4-chloro-3-indolyl- $\beta$-D-galactoside) was purchased from Amersham (Buckinghamshire, UK). Propidium iodide (PI) was purchased from Invitrogen (Carlsbad, CA, USA). $\beta$-Mercaptoethanol was purchased from Merck (Darmstadt, Germany). RNase A was purchased from Qiagen (Hilden, Germany). LDL, trypsin/EDTA solution, 4-methylumbelliferyl- $\beta$-D-galactopyranoside (MUG), 3-\{(3-cholamidopropyl)dimethylammonio\}-1-propanesulfonate hydrate (CHAPS), phenylmethanesulfonyl fluoride (PMSF), PVDF membrane, and all other reagents were purchased from Sigma (St. Louis, MO, USA).

Various antibodies were used in this study. Anti-human $\mathrm{pRb}$ and anti-human phospho-pRb (pS807/pS811) monoclonal antibodies were purchased from BD Biosciences (San Jose, CA, USA). Polyclonal antibodies against p16-INK4A, cyclin E2, and p53 and monoclonal antibodies against cyclin D1 and p21-CIP1 were purchased from Cell Signaling Technology (Danvers, MA, USA). Monoclonal antibodies against
LDL receptor (LDLR), CDK2 and, CDK4 were purchased from Santa Cruz Biotechnology (Santa Cruz, CA, USA). Anti-actin polyclonal antibody and HRP-conjugated antirabbit or anti-mouse secondary antibodies were purchased from Sigma (St. Louis, MO, USA).

2.2. Cell Culture. HUVECs were cultured in EGM-2 medium at $37^{\circ} \mathrm{C}$ under a humidified atmosphere and $5 \% \mathrm{CO}_{2}$. The cells were either subcultured or cultured continuously on a Petri dish for up to 9 days. Young HUVECs [population doubling level (PDL), 12 15] were inoculated on a Petri dish, stabilized by overnight incubation, and then treated with various concentrations of $\mathrm{nLDL}(0,2,5$, or $10 \mu \mathrm{g}$ protein $/ \mathrm{mL}$ ). Media exchange and $\mathrm{nLDL}$ treatment were performed concomitantly at intervals of 3 days. For each subculture, the same number of cells were reinoculated on the same-sized Petri dish. After 3 days of nLDL treatment, the cells were washed thrice with PBS and treated with $0.25 \%$ trypsin/EDTA solution for $3 \mathrm{~min}$. The detached cells were harvested, washed thrice with PBS, and used for various assays.

We cultured the cells by the subculture system by default. Both culture systems used here have disadvantages. Although the subculture system is commonly used, it is stressful to the cells to be harvested and inoculated every 3 days. Continuous culture system causes another type of stress to the cells as a consequence of the inoculation with a lesser number of cells. To eliminate the variables that could occur from each culture system, we used both a subculture system and a continuous culture system for some critical assays.

2.3. Determination of Cellular Proliferation. The cellular proliferation of HUVECs was analyzed by using WST-1 (watersoluble tetrazolium salt-1) based cell viability assay kit (EZCytox) [37]. The nLDL-treated cells $(1.0 \mathrm{~mL})$ were harvested with trypsin/EDTA, mixed with $100 \mu \mathrm{L} / \mathrm{mL}$ of EZ-Cytox solution, and incubated at $37^{\circ} \mathrm{C}$ for $2 \mathrm{hr}$. The mixture was shaken for $1 \mathrm{~min}$ and $200 \mu \mathrm{L}$ of the mixture was transferred to a 96-well microplate. Absorbance of these samples was read at $450 \mathrm{~nm}$ with a microplate reader (Epoch, Winooski, VT, USA).

This assay was carried out in the cells either cultured continuously or subcultured. For subculture, the cells on a Petri dish $\left(6 \times 10^{4}\right.$ cells; $\phi, 35 \mathrm{~mm}$ dish $)$ were subcultured twice concomitantly with nLDL treatment. Cellular proliferation was assayed at the last day of each subculture and expressed as the relative changes in absorbance of the nLDL-treated cells against that of the nLDL-untreated cells of the same culture duration. For continuous culture, the cells on a Petri dish $\left(5 \times 10^{3}\right.$ cells; $\phi, 35 \mathrm{~mm}$ dish) were cultured on the same dish for up to 9 days with nLDL treatment and media exchange. Cellular proliferation was assayed every day and expressed as the relative changes in absorbance of each group of cells to that of the first day inoculated cells without nLDL treatment.

\subsection{Determination of Cellular Senescence}

2.4.1. SA- $\beta$-Gal Activity Assay. The senescence of HUVECs was evaluated by the quantitative SA- $\beta$-gal assay using cell 
extracts [38]. SA- $\beta$-gal activity was measured by quantifying the generation rate of 4-methylumbelliferone (4-MU), the fluorescent hydrolysis product of MUG. Young HUVECs (PDL, 12 15) on a Petri dish $\left(1.0 \times 10^{5}\right.$ cells; $\phi, 10 \mathrm{~cm}$ dish $)$ were subcultured and treated with various concentrations of $\mathrm{nLDL}(0,2,5$, or $10 \mu \mathrm{g}$ protein $/ \mathrm{mL})$ for up to 9 days. On the last day of each subculture, the cells were washed 6 times with PBS to remove residual growth medium protein that could interfere with subsequent cellular protein determination. The cells were then lysed in $450 \mu \mathrm{L}$ of $1 \times$ lysis buffer ( $5 \mathrm{mM}$ CHAPS, $40 \mathrm{mM}$ citric acid, $40 \mathrm{mM}$ sodium phosphate, $0.5 \mathrm{mM}$ benzamidine, and $0.25 \mathrm{mM}$ PMSF, pH 6.0). The lysate was scraped, transferred to a microtube, vortexed vigorously, and centrifuged at $12,000 \times \mathrm{g}$ for $5 \mathrm{~min}$ at $4^{\circ} \mathrm{C}$. The supernatant was kept on ice until further use. Reaction buffer at $2 \times$ strength [ $40 \mathrm{mM}$ citric acid, $40 \mathrm{mM}$ sodium phosphate, $300 \mathrm{mM} \mathrm{NaCl}, 10 \mathrm{mM} \beta$-mercaptoethanol, and $4 \mathrm{mM} \mathrm{MgCl}_{2}$ (pH 6.0)] was mixed with $1.7 \mathrm{mM}$ of MUG (SA$\beta$-gal substrate) immediately prior to its use. The reaction buffer containing MUG $(45 \mu \mathrm{L})$ was mixed with clarified lysate $(30 \mu \mathrm{L})$ and $1 \times$ lysis buffer $(15 \mu \mathrm{L})$. Incubation lasted $1 \mathrm{hr}$, at $37^{\circ} \mathrm{C}$ in a water bath. After the incubation period, the reaction mixture was added to $400 \mathrm{mM}$ sodium carbonate stop solution $(900 \mu \mathrm{L})$ and stored at $4^{\circ} \mathrm{C}$ until measurement of fluorescence. An aliquot of the carbonate-stopped reaction mixture was transferred to a 96 -well plate $(150 \mu \mathrm{L} /$ well $)$ and fluorescence was read with a fluorescence microplate reader (VersaMax, Molecular Devices Corp., Philadelphia, PA, USA) with excitation at $360 \mathrm{~nm}$ and emission at $465 \mathrm{~nm}$. The SA- $\beta$ Gal activity was calculated based on the fluorescence intensity of 4-MU/ $\mu$ g protein and expressed as the relative activity of the nLDL-treated group to the untreated group of the same subculture duration.

2.4.2. SA- $\beta$-Gal Staining. The cellular senescence was also evaluated by the SA- $\beta$-Gal activity-staining assay [39]. Using the same subculture conditions described in Section 2.4.1, and when appropriate, the cells were fixed with $3 \%(\mathrm{v} / \mathrm{v})$ formaldehyde in PBS for 3 5 min and washed thrice with PBS. The washed cells were stained with SA- $\beta-$ Gal staining solution $[1 \mathrm{mg} / \mathrm{mL}$ X-Gal, $40 \mathrm{mM}$ citric acid in $40 \mathrm{mM}$ sodium phosphate buffer ( $\mathrm{pH} 6.0$ ), $5 \mathrm{mM}$ potassium ferricyanide, $5 \mathrm{mM}$ potassium ferrocyanide, $150 \mathrm{mM} \mathrm{NaCl}$, and $2 \mathrm{mM} \mathrm{MgCl}_{2}$ ] at $37^{\circ} \mathrm{C}$ for $16 \mathrm{hr}$ under light protection. The stained cells were washed twice with PBS and coated with 70\% glycerol in PBS. The cells were then observed under a phasecontrast microscope (TS100F, Nikon, Tokyo, Japan).

2.5. Cell Cycle Analysis. Cell cycle of the nLDL-treated HUVECs was analyzed according to the flow cytofluorometric assay using PI staining [40]. Briefly, the cells on a Petri dish $\left(1.0 \times 10^{5}\right.$ cells; $\phi, 10 \mathrm{~cm}$ dish $)$ were subcultured and treated with $\mathrm{nLDL}(0,2,5$, or $10 \mu \mathrm{g}$ protein $/ \mathrm{mL})$ for up to 9 days. When appropriate, the cells were harvested with trypsin/EDTA, washed thrice with PBS, and suspended in $300 \mu \mathrm{L}$ of PBS. The washed cells were fixed in $70 \%$ ice-cold ethanol for $1 \sim 2 \mathrm{hr}$ and washed thrice by centrifuging at $700 \times \mathrm{g}$ for $5 \mathrm{~min}$ in cold PBS. The fixed cells were treated with 50
$100 \mu \mathrm{L}$ of RNase A $(100 \mu \mathrm{g} / \mathrm{mL})$ for $15 \mathrm{~min}$ and then by $100 \mu \mathrm{L}$ of PI $(50 \mu \mathrm{g} / \mathrm{mL})$ for $15 \mathrm{~min}$ under light protection. Cell cycle was analyzed with a FACSCalibur ${ }^{\circledR}$ flow cytometer (BD Biosciences, San Jose, CA, USA) with excitation at $535 \mathrm{~nm}$ and emission at $617 \mathrm{~nm}$.

\subsection{Western Blot Analysis}

2.6.1. Blocking of LDLR with Antibody. To block LDLR, the cells on a Petri dish $\left(2 \times 10^{4}\right.$ cells; $\phi, 35 \mathrm{~mm}$ dish $)$ were pretreated with anti-LDLR antibody $(20 \mu \mathrm{g}$ protein $/ \mathrm{mL})$ for $1 \mathrm{hr}$ at $4^{\circ} \mathrm{C}$. Subsequently, the cells were treated with nLDL $(10 \mu \mathrm{g}$ protein $/ \mathrm{mL})$ and cultured for up to 6 days. Senescence induction was analyzed by SA- $\beta$-Gal activity assay in subcultured cells and cellular proliferation by tetrazolium salt staining in continuously cultured cells every 3 days.

2.6.2. Analysis of Cell Cycle-Regulating Proteins. Cell cycleregulating proteins in HUVECs were analyzed by Western blot. As described in Section 2.6.1., the cells were subcultured for up to 6 days and lysed in the RIPA lysis buffer $(50 \mathrm{mM}$ Tris- $\mathrm{HCl}, 150 \mathrm{mM} \mathrm{NaCl}, 1 \% \mathrm{NP}-40,0.5 \%$ sodium deoxycholate, $0.1 \%$ SDS, and $0.004 \%$ sodium azide) containing $1 \mathrm{mM}$ PMSF, $0.5 \mathrm{mM}$ sodium orthovanadate, and a protease inhibitor cocktail (10 20 $\mu \mathrm{L}$ per $1 \mathrm{~mL}$ lysis buffer). The mixtures were incubated at $4^{\circ} \mathrm{C}$ for $30 \mathrm{~min}$ and centrifuged at $12,000 \times \mathrm{g}$ for $15 \mathrm{~min}$ at $4^{\circ} \mathrm{C}$. The supernatants were stored at $-80^{\circ} \mathrm{C}$ until further use.

Cell lysates $(40 \mu \mathrm{g}$ protein) were separated by $8 \sim 15 \%$ gradient polyacrylamide gel electrophoresis and transferred to a PVDF membrane. The membrane was blocked with $5 \%$ skimmed milk in TBS-T buffer (Tris buffered saline-Tween20 buffer; $137 \mathrm{mM} \mathrm{NaCl}, 2.7 \mathrm{mM} \mathrm{KCl}$, and $0.1 \%$ Tween-20 in $25 \mathrm{mM}$ Tris-base buffer, $\mathrm{pH}$ 7.4) at room temperature for $1 \mathrm{hr}$ and incubated overnight with primary antibody at $4^{\circ} \mathrm{C}$. After washing thrice in TBS-T buffer, the blot was incubated with the secondary antibody [HRP-conjugated anti-rabbit $(1: 2,000)$ or anti-mouse $(1: 5,000)]$ for $2 \mathrm{hr}$ at room temperature. The antibody-specific proteins were detected using the West-ZOL (plus) Western blot detection system (iNtRON Biotechnology, Seongnam, Korea). The primary antibodies were used in the following dilutions: anti-p53 $(1: 1,000)$, antip21-CIP1 $(1: 1,000)$, anti-p16-INK4A $(1: 1,000)$, anti-CDK2 $(1: 1,000)$, anti-CDK4 $(1: 1,000)$, anti-cyclin E2 $(1: 1,000)$, anti-cyclin D1 (1:1,000), anti-pRb (1:250), anti-human pS807/pS811-pRb $(1: 250)$, and anti-actin $(1: 2,500)$.

2.7. Measurement of Intracellular ROS. ROS generation in the nLDL-treated HUVECs was analyzed by the method of Royall and Ischiropoulos [41] to evaluate whether intracellular ROS were implicated in the premature senescence of the cells. Young HUVECs on a culture dish $\left(1.0 \times 10^{5}\right.$ cells; $\phi, 10 \mathrm{~cm}$ dish) were subcultured and treated with various concentrations of nLDL $(0,2,5$, or $10 \mu \mathrm{g}$ protein $/ \mathrm{mL})$ for up to 9 days. When appropriate, the cells were washed twice with HBSS and incubated at $37^{\circ} \mathrm{C}$ for $1 \mathrm{hr}$ in a reaction mixture containing $11 \mu \mathrm{M}$ DCF-DA and $10 \mathrm{mM}$ Hepes, $\mathrm{pH} 7.4$, in phenol-red free EGM-2 medium. After incubation, the cells 


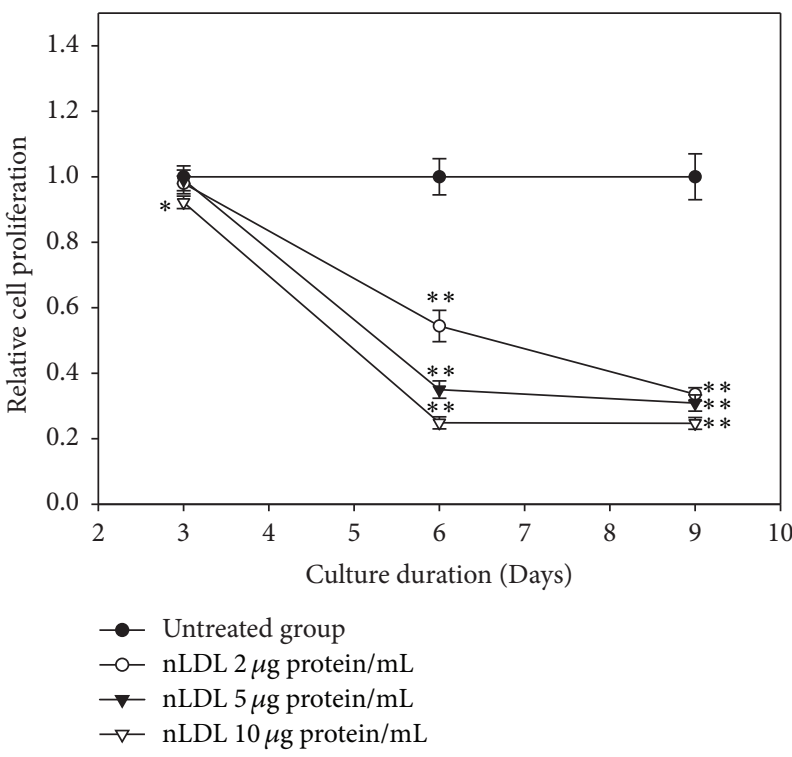

(a)

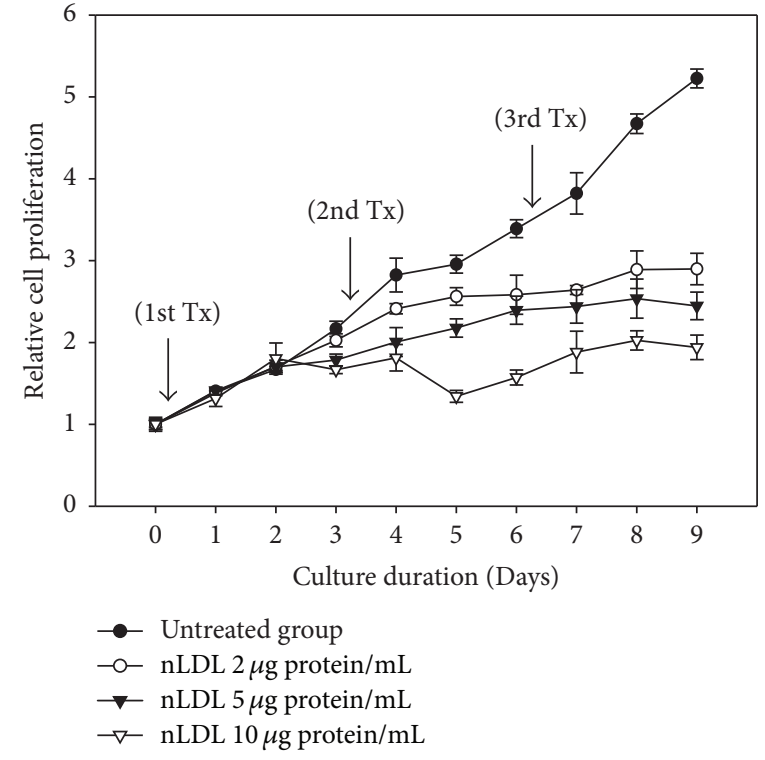

(b)

FIGURE 1: Effect of long-term treatment of nLDL on the proliferation of HUVECs. Young HUVECs (PDL, 12 15) were subcultured at every third day of each subculture with media exchange (a) and cultured continuously in the same culture dish with media exchange (b), for up to 9 days. The cells were treated with various concentrations of $\mathrm{nLDL}(0,2,5$, and $10 \mu \mathrm{g}$ protein $/ \mathrm{mL})$ concomitantly with media exchange every 3 days at both culture systems (1st, 2nd, and 3rd Tx). Cellular proliferation of the cells was analyzed by tetrazolium salt method. The degree of cellular proliferation was expressed as the relative ratio of cell number. The dose- and time-dependent differences in cellular proliferation between groups were analyzed statistically by repeated measures ANOVA assay $(p<0.01)$. Each nLDL-treated group was also compared with the respective nLDL-untreated group by independent $t$-test. ${ }^{*} p<0.05 ;{ }^{* *} p<0.01$. Each result represents the mean \pm SD $(n=6)$.

were washed twice with HBSS, supplemented with $1.5 \mathrm{~mL}$ of sonication buffer $(50 \mathrm{mM}$ potassium phosphate buffer, $\mathrm{pH}$ 7.0, 0.1 mM EDTA, and 0.1\% CHAPS), and harvested by scraping. The cells were lysed by sonication (frequency, $24 \mathrm{~Hz}$; duration, $10 \mathrm{sec} /$ cycle; repetition, 6 cycles; time interval, $10 \mathrm{sec})$. An aliquot of supernatants $(200 \mu \mathrm{L} /$ well $)$ was transferred to a 96-well plate and fluorescence was measured with a fluorescence microplate reader at excitation $502 \mathrm{~nm}$ and emission $523 \mathrm{~nm}$. Intracellular content of ROS was expressed as the relative fluorescence intensity/ $\mu \mathrm{g}$ protein of the nLDL-treated group to untreated group of the same culture duration.

Intracellular generation of ROS was also observed under fluorescent microscopy. DCF-DA-treated HUVECs were washed with HBSS twice and observed with an inverted fluorescence microscope (TE2000-U, Nikon, Japan) at 100x magnification.

\subsection{Protein Quantification and Statistical Analysis. Protein} concentration of each sample was measured by BCA ${ }^{\circledR}$ protein assay kit (Pierce Biotechnology, Rockford, IL, USA). Bovine serum albumin was used as a protein standard.

Statistical analysis was performed by using SPSS Statistics 19 (IBM Corp., Armonk, NY, USA). The dose- and timedependent differences between the groups were analyzed by repeated measures ANOVA assay and simple difference between the data was analyzed by independent $t$-test. $p<0.05$ was considered statistically significant. Data was expressed as mean \pm standard deviation (SD).

\section{Results}

3.1. Native LDL Inhibited Proliferation of HUVECs. The cellular proliferation assay was carried out to evaluate the effect of low concentrations of $\mathrm{nLDL}(0,2,5$, or $10 \mu \mathrm{g}$ protein $/ \mathrm{mL})$ on the proliferation of cultured HUVECs (Figure 1). The effect of nLDL treatment on cellular proliferation was analyzed in both a subculture system (Figure 1(a)) and a continuous culture system (Figure 1(b)). Native LDL treatment significantly inhibited cell proliferation dose- and time-dependently in both culture systems $(p<0.01)$. Cells treated with nLDL for 3 days in a subculture system showed no significant inhibition of cellular proliferation, except at $10 \mu \mathrm{g}$ protein $/ \mathrm{mL}(p<$ 0.05). Nevertheless, cells treated with nLDL for 6 or 9 days showed a significant inhibition of cellular proliferation $(p<$ 0.01 ) for all concentrations tested. The inhibition of cell proliferation occurred after 2 days of nLDL treatment in a continuous culture system. The trypan blue assay of the nLDLtreated cells showed that cell death in this study was negligible (data not shown). These results showed that treatment with low concentrations of nLDL could inhibit the proliferation of cultured HUVECs in a dose- and time-dependent way.

3.2. Native LDL-Induced Senescence of HUVECs. Next, we evaluated the role of senescence of HUVECs in the nLDLinduced inhibition of cellular proliferation. The cells were treated with low concentrations of nLDL $(0,2,5$, and $10 \mu \mathrm{g}$ protein $/ \mathrm{mL}$ ) and cellular senescence was analyzed by 


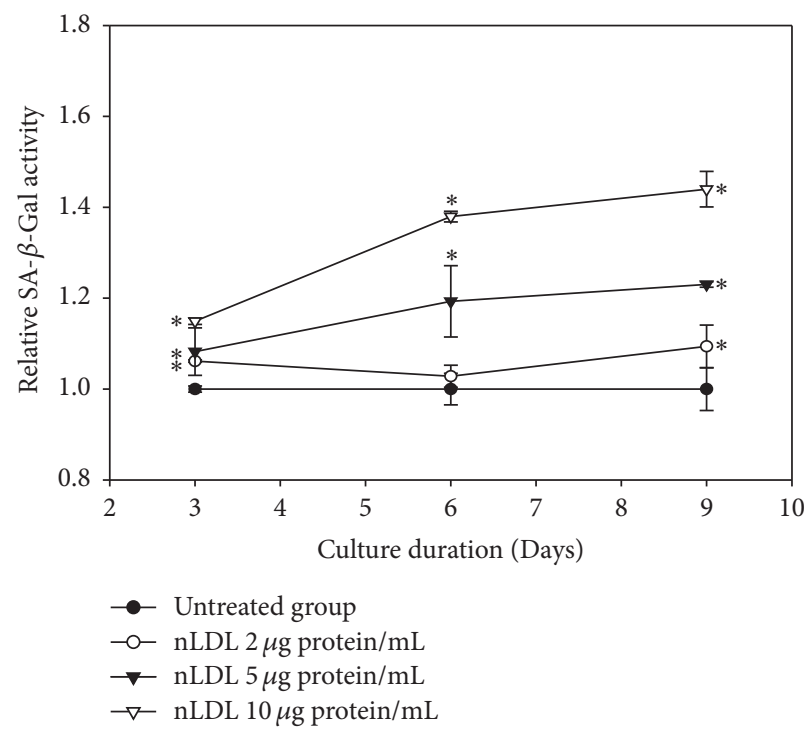

(a)

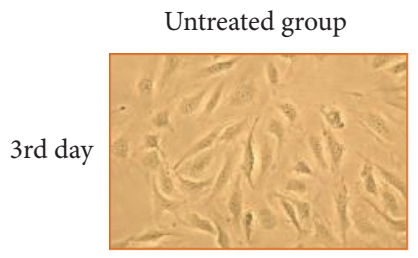

$\mathrm{nLDL} 2 \mu \mathrm{g}$ protein $/ \mathrm{mL}$

$\mathrm{nLDL} 5 \mu \mathrm{g}$ protein/mL
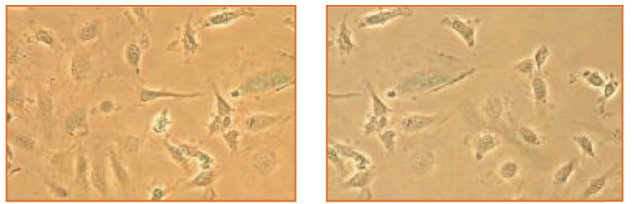

$\mathrm{nLDL} 10 \mu \mathrm{g}$ protein/mL
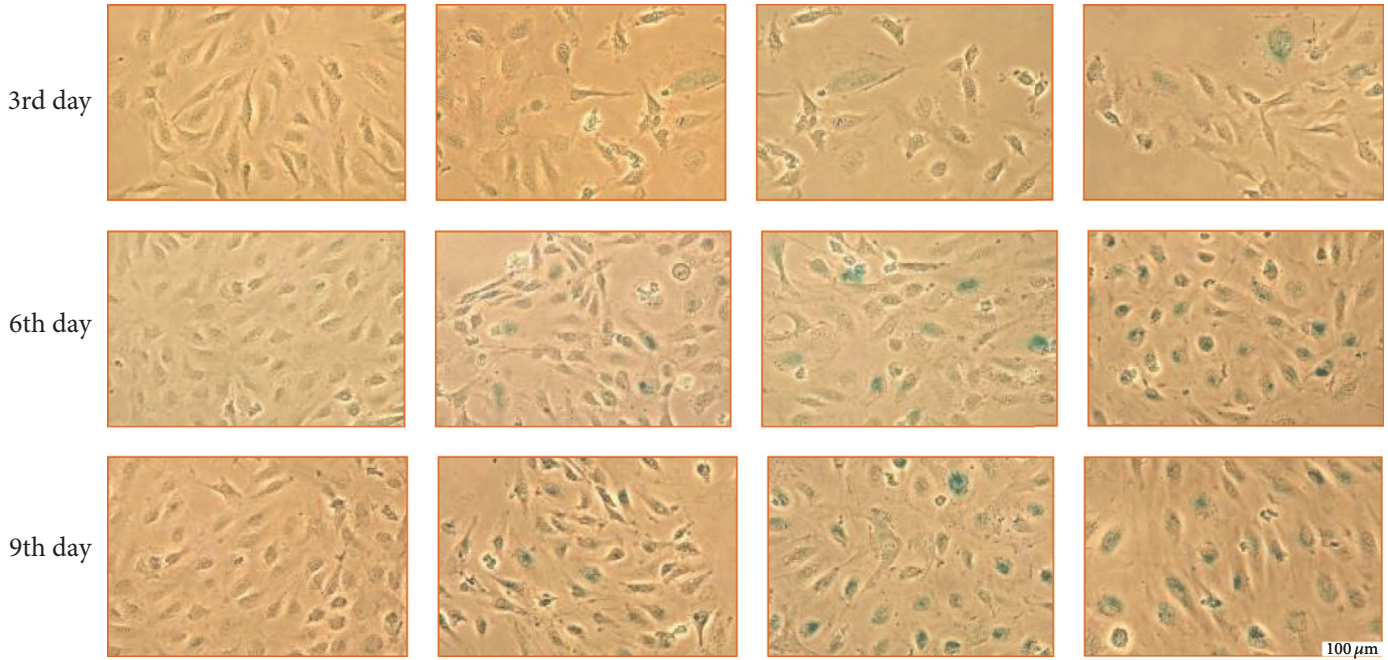

(b)

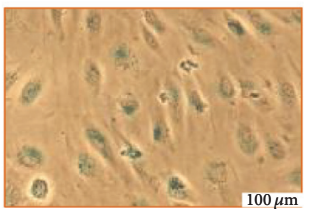

FIgURE 2: Senescence induction in HUVECs by long-term treatment of nLDL (0,2,5, and $10 \mu \mathrm{g}$ protein/mL), for up to 9 days. (a) Quantitative assay of SA- $\beta$-Gal activity after nLDL treatment; (b), SA- $\beta$-Gal activity staining after nLDL treatment. HUVECs were treated with nLDL at the start of each subculture and assayed for SA- $\beta$-Gal activity at the end of each subculture. The SA- $\beta$-Gal activity was expressed as the generation rate of 4-methylumbelliferone (MU)/ $\mu$ g protein against that of the nLDL-untreated group. The dose- and time-dependent differences in SA$\beta$-Gal activity between groups (a) were analyzed statistically by repeated measures ANOVA assay $(p<0.01)$. Each nLDL-treated group was also compared with the respective nLDL-untreated group by independent $t$-test $\left({ }^{*} p<0.01\right)$. Each result represents the mean \pm SD $(n=3)$.

quantitative assay (Figure 2(a)) as well as staining (Figure $2(\mathrm{~b}))$ of SA- $\beta$-Gal activity in a subculture system for up to 9 days. Native LDL significantly increased the enzyme activity dose- and time-dependently in the quantitative assay $(p<0.01)$. Native LDL also increased staining of the enzyme activity. The SA- $\beta$-Gal activity of each nLDL-treated group was also compared with the respective nLDL-untreated group by independent $t$-test. The SA- $\beta$-Gal activity was significantly increased at 3, 6, and 9 days of all concentrations of the nLDL treatment $(p<0.01)$. The increased SA- $\beta-$ Gal activity preceded the decreased cellular proliferation for the lower
nLDL concentrations. These results suggested that the nLDLinduced inhibition of cellular proliferation could at least partly result from cellular senescence.

3.3. Native LDL-Induced Senescent Cells Were Arrested at G1 Phase of Cell Cycle. In the next experiment, we analyzed the change in the distribution of cell cycle phase of the nLDLinduced senescent HUVECs, in a subculture system $(0,2,5$, and $10 \mu \mathrm{g}$ protein $/ \mathrm{mL}$ ) for up to 9 days (Figure 3). Cell cycle analysis with flow cytometry after PI staining indicated that the distribution of G1 phase cells was significantly increased 


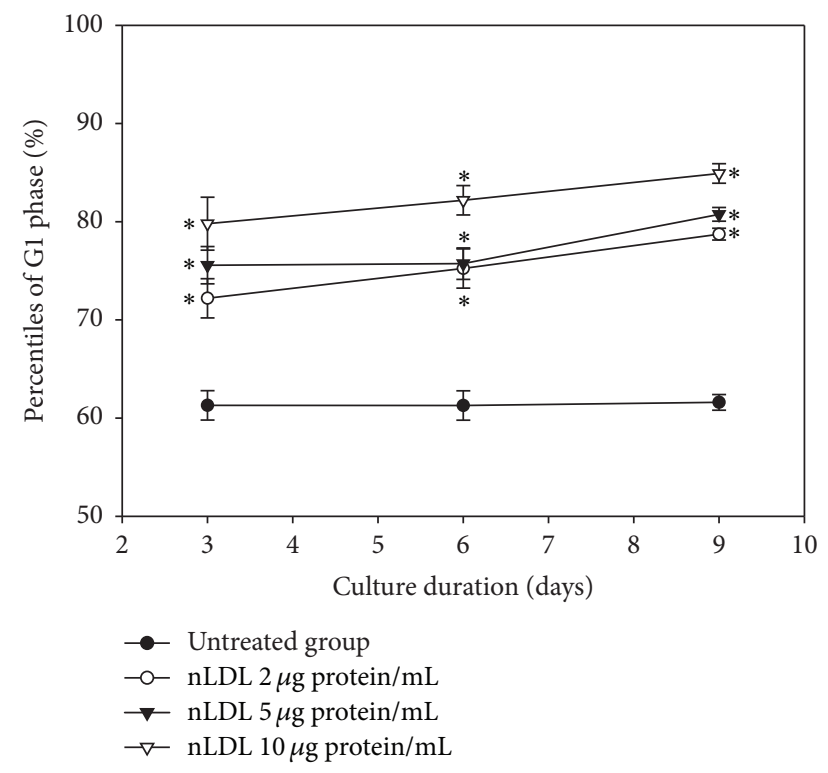

FIGURE 3: G1 arrest induction in HUVECs by long-term treatment of nLDL. Cell cycle was assayed by flow cytometry in the nLDLtreated cells, for up to 9 days, at the end of each subculture. The distribution percentiles of G1 phase cells after nLDL treatment ( 0 , 2,5 , and $10 \mu \mathrm{g}$ protein $/ \mathrm{mL}$ ) were shown as a line graph. The doseand time-dependent differences in G1 phase distribution between groups were analyzed statistically by repeated measures ANOVA assay $(p<0.01)$. Each nLDL-treated group was also compared with the respective nLDL-untreated group by independent $t$-test $\left({ }^{*} p<0.01\right)$. Each result represents the mean $\pm \mathrm{SD}(n=6)$.

$(p<0.01)$ and the distribution of S and G2/M phase cells was significantly decreased (data not shown, $p<0.01$ ) in a dose- and time-dependent way. The distribution of G1 phase cells at each nLDL-treated group was also compared with the respective nLDL-untreated group by independent $t$-test. The distribution of G1 phase cells was significantly increased at all concentrations of nLDL tested $(p<0.01)$. These results indicated that the nLDL-induced senescent HUVECs were arrested at G1 phase of cell cycle.

\subsection{Native LDL-Induced Cellular Senescence Resulted from} NLDL Itself. To confirm that the nLDL-induced cellular senescence in HUVECs did not result from oxLDL generated from nLDL during in vitro incubation, we pretreated the cells with the monoclonal antibody against LDLR (anti-LDLR antibody) to block cellular LDLR before nLDL treatment $(10 \mu \mathrm{g}$ protein $/ \mathrm{mL})$. The SA- $\beta$-Gal activity assay (Figure $4(\mathrm{a})$ ) was carried out in subcultured cells and the cellular proliferation assay (Figure 4(b)) was carried out in continuously cultured cells. Both assays were performed at the cells cultured for up to 6 days, since $10 \mu \mathrm{g}$ protein/mL nLDL showed nearly maximum effect at 6 days (Figures $1(a)$ and 2(a)). The effect of nLDL on both cellular senescence parameters was significantly and negatively modulated by anti-LDLR antibody pretreatment at independent $t$-test $(p<0.01)$ as well as repeated measures ANOVA assay $(p<0.01)$. These results suggested that the nLDL-induced cellular senescence of HUVECs resulted from nLDL itself, and not oxLDL.

3.5. Cellular Senescence by NLDL Was Induced via Both $p 53$ and p16-pRb Signal Pathways. To evaluate the signal transduction pathway involved in senescence induction with $\mathrm{nLDL}(10 \mu \mathrm{g}$ protein $/ \mathrm{mL})$, we conducted Western blot analysis for some cell cycle-regulating proteins at the last day of each subculture (Figure 5) for up to 6 days. As expected, the content of p53, p21, and p16 proteins was significantly increased in the nLDL-induced senescent cells (B-1). Two cyclin/CDK complexes such as CDK4/6-cyclin D and CDK2cyclin $\mathrm{E}$ are known to phosphorylate $\mathrm{pRb}$ to overcome G1 arrest. The protein content of these complexes, that is, CDK2, cyclin E2, CDK4, and cyclin D1, was significantly decreased in the senescent cells (B-2 and B-3); and, as a result, the phosphorylation of $\mathrm{pRB}$ was also significantly inhibited (B4). These results suggested that the nLDL-induced cellular senescence in HUVECs could result from the inhibition of $\mathrm{pRb}$ phosphorylation (i.e., G1 arrest of cell cycle) by the inhibition of the two cyclin/CDK complexes (CDK4/6cyclin D and CDK2-cyclin E) via both the p53 and p16 signal transduction pathways. Pretreatment with anti-LDLR antibody restored in varying degrees the changes in the levels of the cell cycle-regulating proteins induced by nLDL treatment (Figure 5). These results corroborated the results of Figure 4 that pretreatment of anti-LDLR antibody prevented senescence induction in HUVECs.

3.6. Native LDL-Induced Senescent Cells Were Arrested Permanently at G1 Phase. Although G1-arrested young cells can be reactivated to proliferating cells by treating with serum or other mitogenic agents, senescent cells theoretically cannot overcome the G1 checkpoint. In line with this, we tried to determine whether the nLDL-induced G1 phase arrest of HUVECs was a temporary or a permanent phenomenon. As a matter of convenience, we wanted to show the irreversibility of cellular senescence (i.e., G1 arrest) induced by the lowest concentration of nLDL. If cellular senescence induced by the lowest concentration of $\mathrm{nLDL}(2 \mu \mathrm{g} / \mathrm{mL})$ was not reversed, cellular senescence by higher concentrations of nLDL would be irreversible. After inducing cellular senescence by nLDL treatment $(2 \mu \mathrm{g}$ protein $/ \mathrm{mL})$ with subculture for up to 9 days (first cycle of subculture), the cells were washed with EGM2 medium twice and subcultured again in the same medium without nLDL for up to 6 days (second cycle of subculture). We thought that subculture for 6 days would be enough to show the cell proliferating trend at in vitro culture condition. Flow cytometric cell cycle analysis with PI was carried out subsequently.

The first cycle of subculture with nLDL treatment increased the distribution of G1 phase cells, as compared to the nLDL-untreated cells (Figure 3). After washing out nLDL, the second cycle of subculture for up to 6 days failed to return the cells to their original proliferative state $(p>0.05$; Table 1). The G1-arrest of HUVECs induced by the lowest concentration of $\mathrm{nLDL}(2 \mu \mathrm{g}$ protein $/ \mathrm{mL})$ was not reversed by washing out nLDL from the cells. This result indicated that 


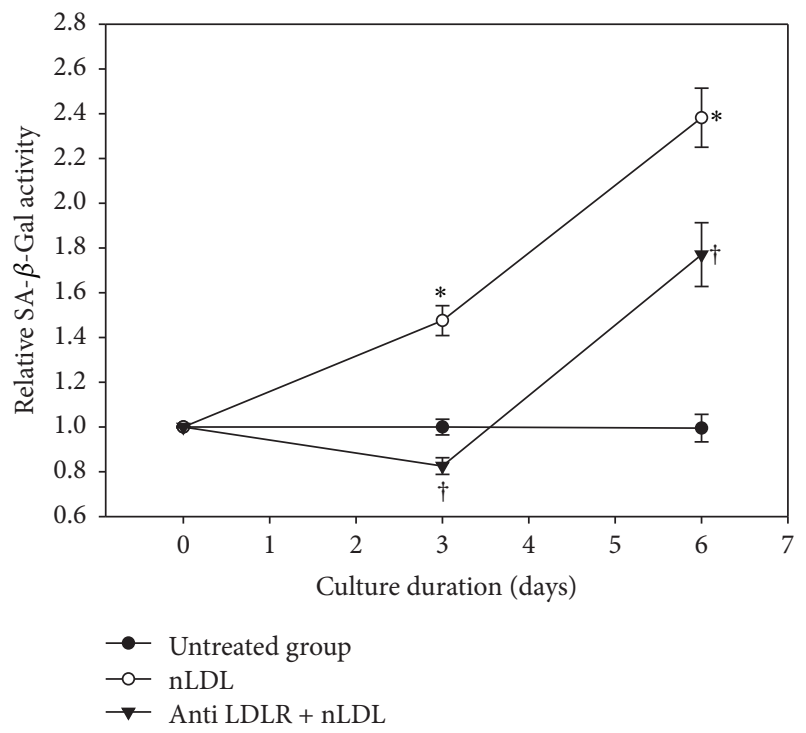

(a)

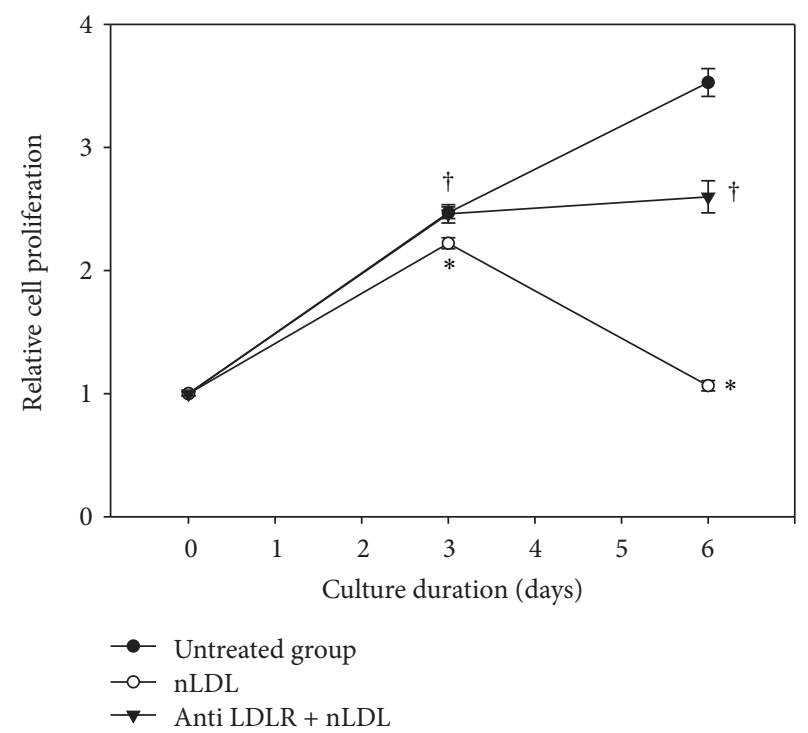

(b)

FIGURE 4: Effect of LDL receptor (LDLR) blocking with antibody on the nLDL-induction of senescence in HUVECs. The cells were pretreated with anti-LDLR antibody $(20 \mu \mathrm{g}$ protein $/ \mathrm{mL})$ before $\mathrm{nLDL}(10 \mu \mathrm{g}$ protein $/ \mathrm{mL})$ treatment. The cells were cultured for up to 6 days. Senescence induction was carried out by SA- $\beta$-Gal activity assay in subcultured cells (a) and cellular proliferation by tetrazolium salt staining in continuously cultured cells (b), every 3 days. The time-dependent difference in SA- $\beta$-Gal activity or cellular proliferation between treatment groups was analyzed statistically by repeated measures ANOVA assay $(p<0.01)$. And also, each nLDL-treated group was compared with the respective nLDL-untreated group $\left({ }^{*} p<0.01\right)$ and each anti-LDLR antibody plus nLDL-treated group was compared with the respective $\mathrm{nLDL}$-treated group $\left({ }^{\dagger} p<0.01\right)$ by independent $t$-test. Each result represents the mean $\pm \mathrm{SD}(n=6)$.

nLDL-induced senescence of cultured endothelial cells was an irreversible change.

3.7. Intracellular ROS Generation Was Implicated in NLDLInduced Cellular Senescence. In this experiment, we determined the role of ROS in the nLDL-induced senescence of HUVECs. The cells were treated with $\operatorname{nLDL}(0,2,5$, and $10 \mu \mathrm{g}$ protein $/ \mathrm{mL}$ ) concomitantly with media exchange in a subculture system for up to 9 days. ROS generation in the nLDL-treated cells was measured by spectrofluorometry (Figure 6(a)) and fluorescence microscopy (Figure 6(b)) with DCF-DA as a chemical probe. The intracellular ROS generation was significantly increased in the nLDL-treated cells dose- and time-dependently ( $p<0.01$ ). Cells treated with nLDL for 3 days in a subculture system showed no significant ROS generation by independent $t$-test. Nevertheless, cells treated with nLDL for 6 or 9 days showed a significant increase in ROS generation $(p<0.05$ or 0.01 ) for all concentrations tested.

\section{Discussion}

In this study, we used both a subculture system and a continuous culture system to eliminate the variables that could occur from each culture system for up to 9 days of culture. Long-term treatment with low concentrations of nLDL (2 10 $\mu \mathrm{g}$ protein $/ \mathrm{mL})$ inhibited the proliferation of HUVECs in both culture systems. The inhibition of cell proliferation was shown after 2 days of nLDL treatment, suggesting that as the concentrations of nLDL were very low, the effect required amplification within the cells. The result that the endothelial cell's senescence induced by nLDL treatment preceded their decreased proliferation suggested that the cellular senescence might be responsible for the decreased cellular proliferation. We first showed that nLDL could induce premature senescence of cultured cells.

The cellular distribution to G1 phase was increased by nLDL treatment. The nLDL-induced senescent cells were arrested at G1 phase of cell cycle. Moreover, the senescent cells did not escape from G1-arrest even on consecutive subculture for up to 6 days after removal of nLDL. These results suggest that the nLDL-induced G1-arrest of HUVECs is permanent and irreversible.

The oxidative status of nLDL itself is very important in this study, since oxLDL might induce premature senescence of cultured cells. The oxidative status of nLDL isolated from the serum of healthy men has been found variable. Colas et al. [42] reported that the degree of lipid peroxidation of LDL was about $245 \mathrm{fmol}$ malondialdehyde (MDA)/ $\mu \mathrm{g}$ LDL protein (49.5 pmol MDA/mg cholesterol). However, Han and Pak [43] reported a much lower degree of lipid peroxidation ( $0.8 \mathrm{fmol} \mathrm{MDA} / \mu \mathrm{g}$ LDL protein). The lipid peroxidation level of nLDL used in this study was $8.4 \mathrm{fmol} \mathrm{MDA} / \mu \mathrm{g}$ LDL protein. The oxidative status of the nLDL used in this study was about 30 times lower than the value by Colas et al. [42] but about 10 times higher than the value by Han and Pak [43]. Thus, the nLDL used in this study is within the normal range of oxidative status from healthy men. 


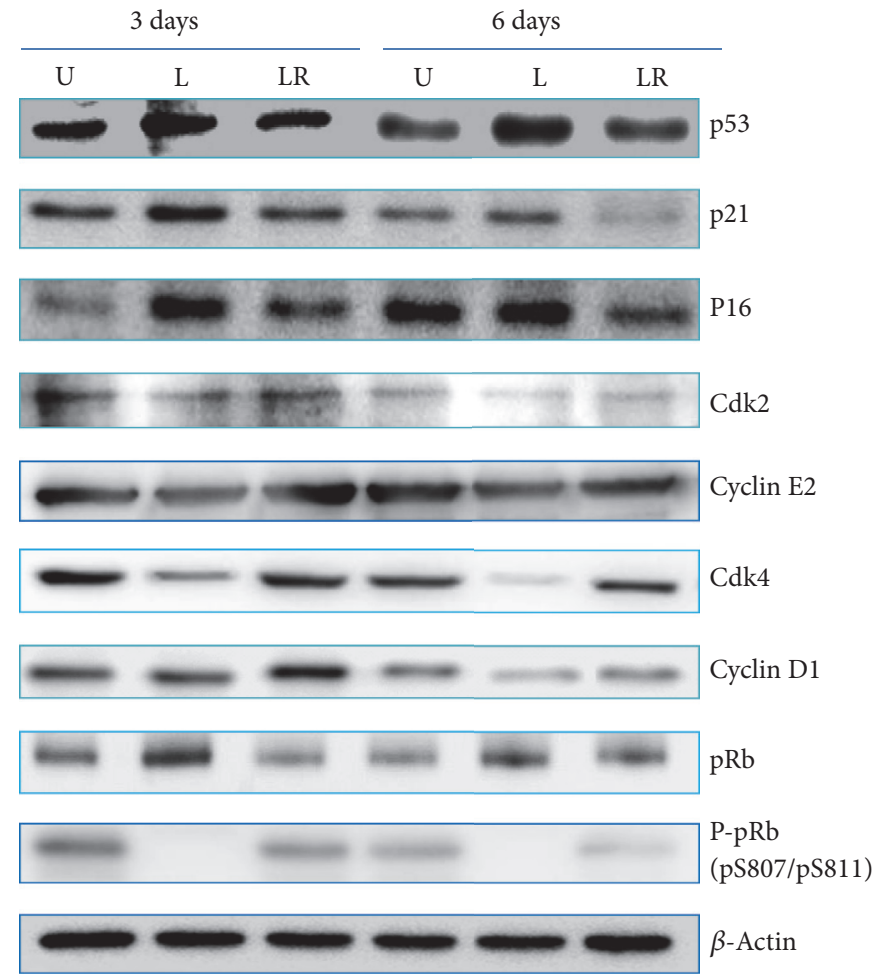

(a)

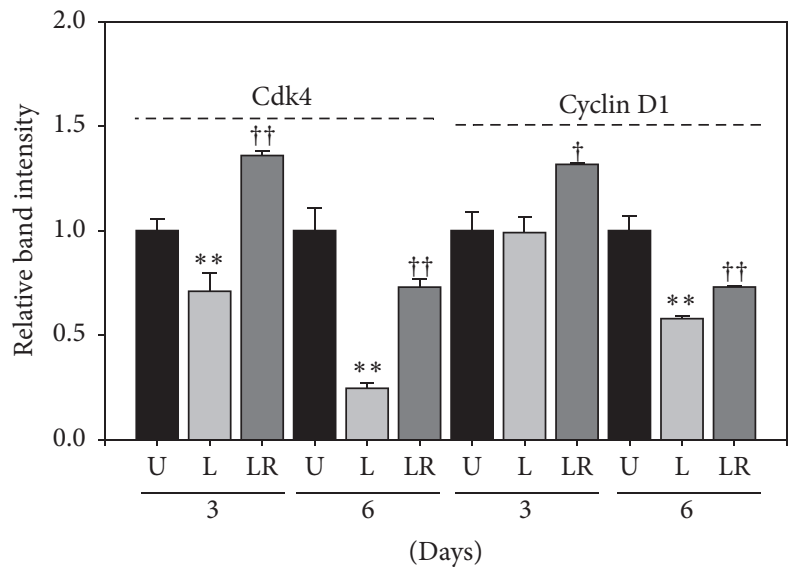

(b3)

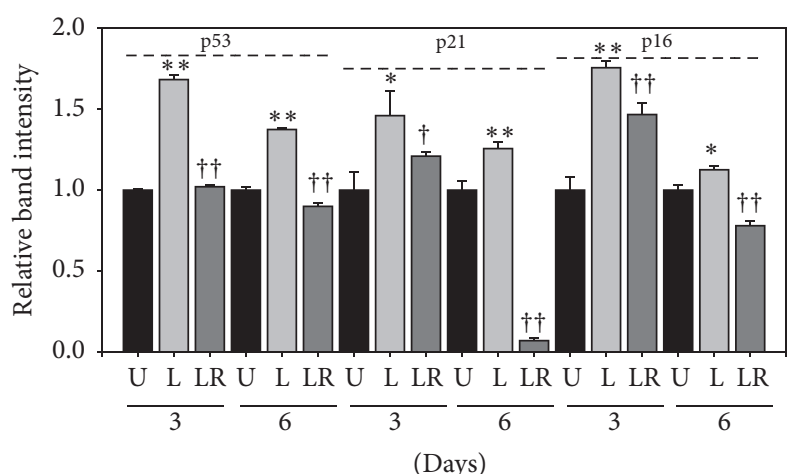

(b1)

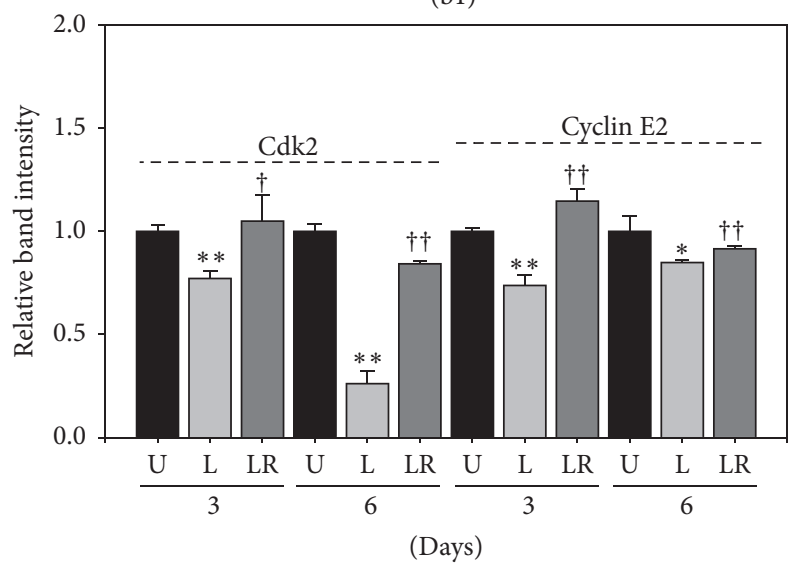

(b2)

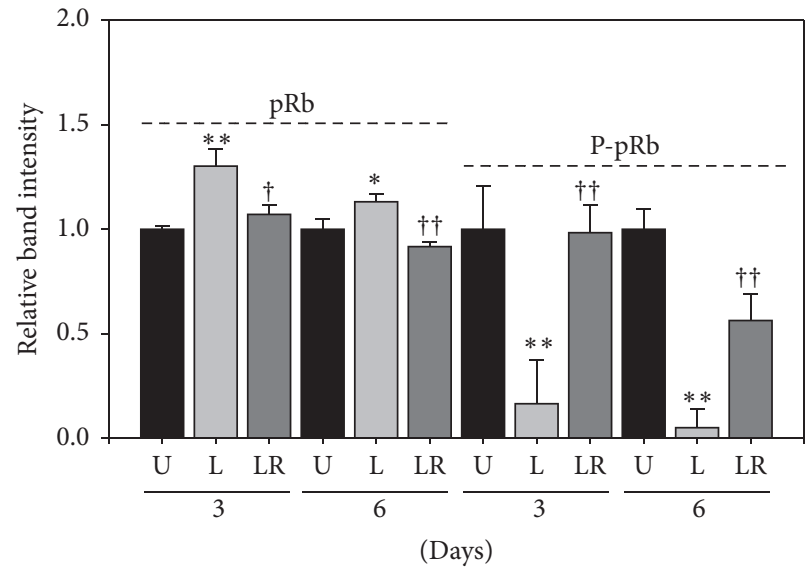

(b4)

FIGURE 5: Changes in the content of some cell cycle-regulating proteins by long-term treatment of nLDL (10 $\mu \mathrm{g}$ protein/mL) in HUVECs and their restoration by pretreatment with anti-LDLR $(20 \mu \mathrm{g}$ protein $/ \mathrm{mL})$. The cells were untreated with $\mathrm{nLDL}(\mathrm{U})$, treated with $\mathrm{nLDL}(\mathrm{L})$, or treated with both anti-LDLR and nLDL (LR) at each subculture, for up to 6 days. At the end of each subculture, the content of some cell cycleregulating proteins was assayed by Western blot analysis. (a) Western blot images; (b) quantification of Western blot bands. (b1) The contents of 53, p21, and p16 proteins were increased by nLDL treatment, with these effects compromised by the anti-LDLR pretreatment. (b2) The nLDL-induced decrease in Cdk2 and Cyclin E2 was compromised by the anti-LDLR pretreatment. (b3) The nLDL-induced decrease in Cdk4 and Cyclin D1 was compromised by anti-LDLR pretreatment. (b4) The content of pRb was increased and that of P-pRb (phosphorylated pRb) was decreased, with these effects compromised by the anti-LDLR pretreatment. Group L was compared with the nLDL-untreated group (U) by independent $t$-test $\left({ }^{*} p<0.05\right.$ and $\left.{ }^{* *} p<0.01\right)$. Group LR was compared with group L by independent $t$-test $\left({ }^{\dagger} p<0.05\right.$ and $\left.{ }^{\dagger \dagger} p<0.01\right)$. 
TABLE 1: Native LDL-induced G1 arrest of HUVECs was not reversed by nLDL removal. The cells were treated with $\mathrm{nLDL}(2 \mu \mathrm{g}$ protein/mL) for 3, 6, and 9 days (first cycle of subculture) and the G1-arrested cells were subcultured again for 3 and 6 days without nLDL (second cycle of subculture). Cell cycle was analyzed by flow cytometry at the end of second subculture. The 3 and 6 days groups of the second cycle of subculture were compared with the 0 day group of the second cycle of subculture by independent $t$-test $(p>0.05)$. Each result represents the mean $\pm \operatorname{SD}(n=3-4)$.

\begin{tabular}{|c|c|c|c|}
\hline $\begin{array}{l}\text { First cycle of subculture of nLDL pretreatment } \\
(2 \mu \mathrm{g} \text { protein } / \mathrm{mL})\end{array}$ & $\begin{array}{l}\text { Second cycle of subculture } \\
\text { after nLDL removal }\end{array}$ & G1 phase & $p$ value \\
\hline \multirow{3}{*}{3 days } & 0 days & $76.2 \pm 0.7$ & \multirow{3}{*}{$p>0.05$} \\
\hline & 3 days & $76.3 \pm 1.7$ & \\
\hline & 6 days & $77.8 \pm 4.5$ & \\
\hline \multirow{3}{*}{6 days } & 0 days & $77.1 \pm 0.7$ & \multirow{3}{*}{$p>0.05$} \\
\hline & 3 days & $77.7 \pm 0.9$ & \\
\hline & 6 days & $79.3 \pm 1.9$ & \\
\hline \multirow{3}{*}{9 days } & 0 days & $80.7 \pm 0.7$ & \multirow{3}{*}{$p>0.05$} \\
\hline & 3 days & $82.5 \pm 0.9$ & \\
\hline & 6 days & $84.8 \pm 2.6$ & \\
\hline
\end{tabular}

Moreover, because nLDL could be oxidized to oxLDL during in vitro culture, we needed to ensure that the senescence was induced not by oxLDL but by nLDL itself. For this purpose, we blocked the receptor for nLDL (LDLR) with the anti-LDLR antibody before nLDL treatment as described by Allen et al. [44], on the basis that oxLDL does not bind to LDLR [45]. Anti-LDLR antibody pretreatment suppressed the nLDL-induced HUVECs senescence. This result suggested that nLDL itself may be endocytosed into the cultured endothelial cells to induce premature senescence of the cells. There is another subfraction of LDL, minimally modified LDL (mmLDL), that is sufficiently modified to be chemically distinguished from nLDL. Despite its modification, mmLDL retains the ability to bind to LDLR [46]. So far, this unusual character of mmLDL makes it hard to differentiate the effect of nLDL from that of mmLDL. Further studies are required to solve this problem.

Next, we tried to identify the signal transduction pathway involved in the nLDL-induced endothelial senescence. Growth arrest of senescent cells is maintained by the p53 and/or p16-pRb signal transduction pathways [47-49]. Hence, we conducted Western blot analysis of some of the cell cycle-regulating proteins that are related to these signal transduction pathways and G1 arrest of senescent cells. The level of p53 was increased. In addition, the level of dephosphorylated form of $\mathrm{pRb}$ was increased, but that of phosphorylated $\mathrm{pRb}$ at $\mathrm{S} 807$ and S811 [P-pRb (pS807/pS811)] was decreased, indicating that suppression of the phosphorylation of the $\mathrm{pRb}$ protein is the cause of senescence induction in the cells. The level of CDK inhibitors such as p21 and p16 was also increased, but the level of cyclin/CDK complex proteins such as Cdk2, Cdk4, Cyclin E2, and Cyclin D1 was decreased. These changes in the level of the cell cycle-regulating proteins in the nLDL-treated cells suggested that nLDL-induced G1 arrest of HUVECs could be due to the inhibition of $\mathrm{pRb}$ phosphorylation through both the p53 and p16-pRb signal transduction pathways.

Pretreatment of anti-LDLR antibody restored in varying degrees the changes in the level of the cell cycle-regulating proteins induced by nLDL treatment. This result corroborated the results of Figure 4 that pretreatment of anti-LDLR antibody prevented nLDL-induced senescence induction in HUVECs.

We also showed that long-term treatment with low concentrations of nLDL could stimulate the generation of ROS in HUVECs. This result suggested that ROS might be implicated in the premature senescence of cultured endothelial cells by nLDL treatment.

The senescence-inducing pathways could be initiated by diverse stressful conditions such as telomere shortening, DNA damage, oncogene activation, lack of nutrients, or growth factors, and oxidative stress $[47,49]$. Native LDL reportedly can generate superoxide radical $\left(\mathrm{O}_{2}^{-\cdot}\right)$ instead of $\mathrm{NO}$ in endothelial cells or tissues, including HUVECs, by uncoupling of eNOS [50-53]. Relatively high concentrations of nLDL (2.4 mg cholesterol $/ \mathrm{mL}$ ) were used in these studies, to show the stimulating effect of nLDL on the generation of ROS in HUVECs. Here, we demonstrated that the premature senescence of the endothelial cells could be induced by longterm treatment, at very low concentrations of nLDL (4.4 $22.2 \mu \mathrm{g}$ cholesterol $/ \mathrm{mL}$ ).

Collectively, our results suggested that long-term treatment with low concentrations of nLDL could induce premature senescence of cultured endothelial cells. Native LDL is endocytosed into the cells through the LDLR and probably generates ROS to induce cellular senescence via both p53 and p16-pRb signal transduction pathways.

The findings from this study are not applicable to in vivo human pathophysiology, since in terms of antioxidant capacity in vitro culture condition is quite different from in vivo cellular environment. Nevertheless, the nLDL-induced senescence of cultured HUVECs could be used as a model system for the study of premature cellular senescence in in vitro aging conditions. Human body, including the circulatory system, has well-developed homeostatic defense systems that can protect from oxidative stress. Nevertheless, when the homeostatic balance between prooxidant and antioxidant 


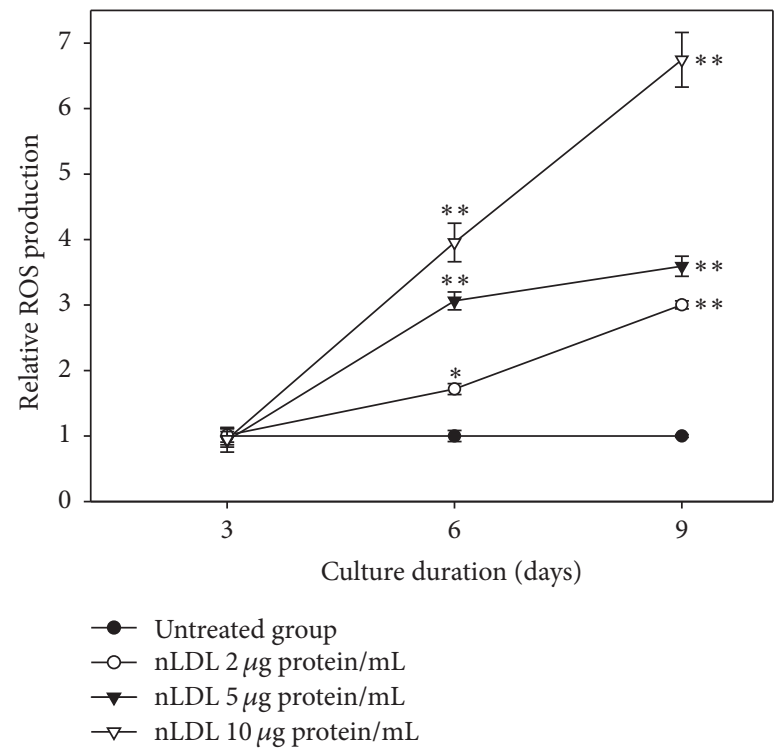

(a)

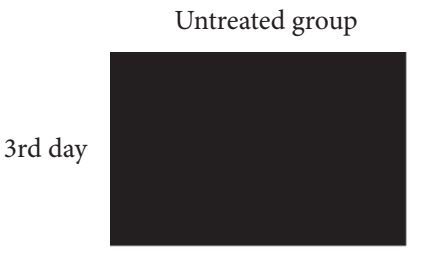

$\mathrm{nLDL} 2 \mu \mathrm{g}$ protein/mL

$\mathrm{nLDL} 5 \mu \mathrm{g}$ protein $/ \mathrm{mL}$

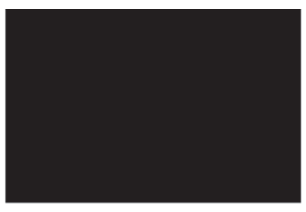

6th day
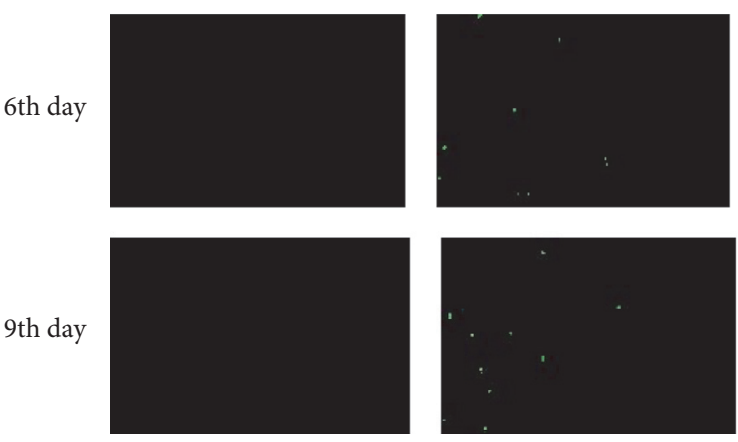
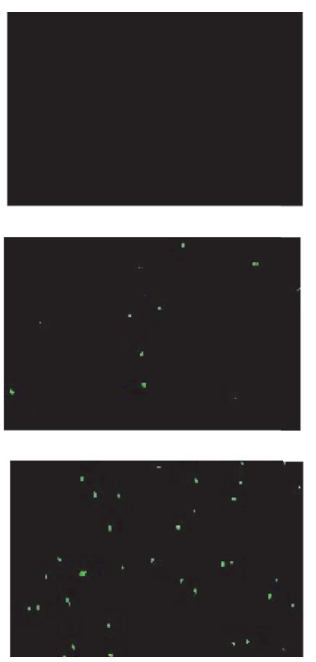

$\mathrm{nLDL} 10 \mu \mathrm{g}$ protein $/ \mathrm{mL}$
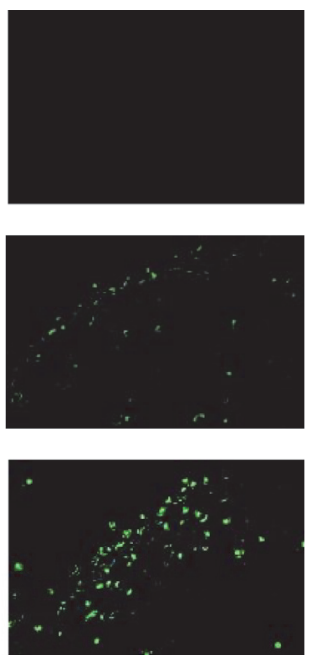

(b)

FIgURE 6: The generation of reactive oxygen species (ROS) with nLDL in HUVECs. The cells were subcultured and treated with nLDL $(0,2,5$, and $10 \mu \mathrm{g}$ protein $/ \mathrm{mL})$ every 3 days of each subculture, for up to 9 days. ROS generation in nLDL-treated cells were analyzed by spectrofluorometry (a) and fluorescence microscopy (b) assays with DCF-DA at the end of each subculture. ROS generation was expressed as the relative fluorescence intensity/ $\mu \mathrm{g}$ of protein of the nLDL-treated group, as compared to the untreated group. The dose- and timedependent differences in ROS generation (a) between groups were analyzed statistically by repeated measures ANOVA assay ( $p<0.01$ ). Each nLDL-treated group was also compared with the respective nLDL-untreated group by independent $t$-test $\left({ }^{*} p<0.05\right.$ and $\left.{ }^{* *} p<0.01\right)$. Each result represents the mean $\pm \mathrm{SD}(n=3-4)$.

system in the plasma and endothelial cells is disturbed for a relatively long period, nLDL as well as modified LDL, such as oxLDL, could induce the premature senescence of vascular endothelial cells.

In summary, this is the first report describing nLDLinduced senescence of vascular endothelial cells, at least, partly via oxidative stress under in vitro culture condition. The nLDL-induced senescence of vascular endothelial cells could be used as a model system for in vitro aging study.
Further studies are required to apply this finding to in vivo human pathophysiology.

\section{Disclosure}

This article contains a part of the degree thesis "Induction of Premature Senescence with Native Low-Density Lipoprotein in Human Vascular Endothelial Cells" by Hoon Park (Doctor of Medical Sciences) at Chonnam National University, 2012. 


\section{Competing Interests}

The authors declare that there is no conflict of interests regarding the publication of this paper.

\section{Authors' Contributions}

Sung-Tack Oh and Hoon Park contributed equally to this work.

\section{Acknowledgments}

This study was supported by grants from Chonnam National University Hospital Research Institute (CRI 11024-1) and from Chonnam National University (2013-2591).

\section{References}

[1] D. S. Celermajer, K. E. Sorensen, D. J. Spiegelhalter, D. Georgakopoulos, J. Robinson, and J. E. Deanfield, "Aging is associated with endothelial dysfunction in healthy men years before the age-related decline in women," Journal of the American College of Cardiology, vol. 24, no. 2, pp. 471-476, 1994.

[2] J. W. Weinsaft and J. M. Edelberg, "Aging-associated changes in vascular activity: a potential link to geriatric cardiovascular disease," American Journal of Geriatric Cardiology, vol. 10, no. 6, pp. 348-354, 2001.

[3] J. P. Strong and H. C. McGill Jr., "The natural history of coronary atherosclerosis," The American Journal of Pathology, vol. 40, pp. 37-49, 1962.

[4] D. A. Eggen and L. A. Solberg, "Variation of atherosclerosis with age," Laboratory Investigation, vol. 18, no. 5, pp. 571-579, 1968.

[5] K. W. Weingand, T. B. Clarkson, M. R. Adams, and A. D. Bostrom, "Effects of age and/or puberty on coronary artery atherosclerosis in cynomolgus monkeys," Atherosclerosis, vol. 62, no. 2, pp. 137-144, 1986.

[6] J. D. Erusalimsky and D. J. Kurz, "Cellular senescence in vivo: its relevance in ageing and cardiovascular disease," Experimental Gerontology, vol. 40, no. 8-9, pp. 634-642, 2005.

[7] J. J. Fuster and V. Andrés, "Telomere biology and cardiovascular disease," Circulation Research, vol. 99, no. 11, pp. 1167-1180, 2006.

[8] T. Minamino and I. Komuro, "Role of telomere in endothelial dysfunction in atherosclerosis," Current Opinion in Lipidology, vol. 13, no. 5, pp. 537-543, 2002.

[9] J. Chen and M. S. Goligorsky, "Premature senescence of endothelial cells: Methusaleh's dilemma," American Journal of Physiology-Heart and Circulatory Physiology, vol. 290, no. 5, pp. H1729-H1739, 2006.

[10] S. Laurent, "Defining vascular aging and cardiovascular risk," Journal of Hypertension, vol. 30, supplement 1, pp. S3-S8, 2012.

[11] J. D. Erusalimsky, "Vascular endothelial senescence: from mechanisms to pathophysiology," Journal of Applied Physiology, vol. 106, no. 1, pp. 326-332, 2009.

[12] M. S. Goligorsky, J. Chen, and S. Patschan, "Stress-induced premature senescence of endothelial cells: a perilous state between recovery and point of no return," Current Opinion in Hematology, vol. 16, no. 3, pp. 215-219, 2009.

[13] C. B. Harley, "Telomere loss: mitotic clock or genetic time bomb?" Mutation Research DNAging, vol. 256, no. 2-6, pp. 271282, 1991.
[14] U. Herbig, W. A. Jobling, B. P. C. Chen, D. J. Chen, and J. M. Sedivy, "Telomere shortening triggers senescence of human cells through a pathway involving ATM, p53, and p21 ${ }^{\mathrm{CIP1}}$, but not p16 INK4a," Molecular Cell, vol. 14, no. 4, pp. 501-513, 2004.

[15] O. Toussaint, E. E. Medrano, and T. Von Zglinicki, "Cellular and molecular mechanisms of stress-induced premature senescence (SIPS) of human diploid fibroblasts and melanocytes," Experimental Gerontology, vol. 35, no. 8, pp. 927-945, 2000.

[16] M. Serrano and M. A. Blasco, "Putting the stress on senescence," Current Opinion in Cell Biology, vol. 13, no. 6, pp. 748-753, 2001.

[17] W. Wang, J. X. Chen, R. Liao et al., "Sequential activation of the MEK-extracellular signal-regulated kinase and MKK3/6-p38 mitogen-activated protein kinase pathways mediates oncogenic ras-induced premature senescence," Molecular and Cellular Biology, vol. 22, no. 10, pp. 3389-3403, 2002.

[18] T. Minamino, H. Miyauchi, T. Yoshida, K. Tateno, T. Kunieda, and I. Komuro, "Vascular cell senescence and vascular aging," Journal of Molecular and Cellular Cardiology, vol. 36, no. 2, pp. 175-183, 2004.

[19] J. C. Jeyapalan and J. M. Sedivy, "Cellular senescence and organismal aging," Mechanisms of Ageing and Development, vol. 129, no. 7-8, pp. 467-474, 2008.

[20] M. Muller, "Cellular senescence: molecular mechanisms, in vivo significance, and redox considerations," Antioxidants and Redox Signaling, vol. 11, no. 1, pp. 59-98, 2009.

[21] K. Kugiyama, S. A. Kerns, J. D. Morrisett, R. Roberts, and P. D. Henry, "Impairment of endothelium-dependent arterial relaxation by lysolecithin in modified low-density lipoproteins," Nature, vol. 344, no. 6262, pp. 160-162, 1990.

[22] B. V. Khan, S. S. Parthasarathy, R. W. Alexander, and R. M. Medford, "Modified low density lipoprotein and its constituents augment cytokine-activated vascular cell adhesion molecule-1 gene expression in human vascular endothelial cells," Journal of Clinical Investigation, vol. 95, no. 3, pp. 1262-1270, 1995.

[23] J. Galle, J. Bengen, P. Schollmeyer, and C. Wanner, "Impairment of endothelium-dependent dilation in rabbit renal arteries by oxidized lipoprotein(a): role of oxygen-derived radicals," Circulation, vol. 92, no. 6, pp. 1582-1589, 1995.

[24] S. Dimmeler, J. Haendeler, J. Galle, and A. M. Zeiher, "Oxidized low-density lipoprotein induces apoptosis of human endothelial cells by activation of CPP32-like proteases: a mechanistic clue to the 'response to injury' hypothesis," Circulation, vol. 95, no. 7, pp. 1760-1763, 1997.

[25] T. Imanishi, T. Hano, T. Sawamura, and I. Nishio, "Oxidized low-density lipoprotein induces endothelial progenitor cell senescence, leading to cellular dysfunction," Clinical and Experimental Pharmacology and Physiology, vol. 31, no. 7, pp. 407-413, 2004.

[26] S. Ehara, M. Ueda, T. Naruko et al., "Elevated levels of oxidized low density lipoprotein show a positive relationship with the severity of acute coronary syndromes," Circulation, vol. 103, no. 15, pp. 1955-1960, 2001.

[27] K. Nishi, H. Itabe, M. Uno et al., "Oxidized LDL in carotid plaques and plasma associates with plaque instability," Arteriosclerosis, Thrombosis, and Vascular Biology, vol. 22, no. 10, pp. 1649-1654, 2002.

[28] T. J. C. Van Berkel, Y. B. De Rijke, and J. K. Kruijt, "Different fate in vivo of oxidatively modified low density lipoprotein and acetylated low density lipoprotein in rats: recognition by various scavenger receptors on Kupffer and endothelial liver cells," Journal of Biological Chemistry, vol. 266, no. 4, pp. 2282-2289, 1991. 
[29] W. Ling, M. Lougheed, H. Suzuki, A. Buchan, T. Kodama, and U. P. Steinbrecher, "Oxidized or acetylated low density lipoproteins are rapidly cleared by the liver in mice with disruption of the scavenger receptor class A type I/II gene," Journal of Clinical Investigation, vol. 100, no. 2, pp. 244-252, 1997.

[30] J. Hulthe and B. Fagerberg, "Circulating oxidized LDL is associated with subclinical atherosclerosis development and inflammatory cytokines (AIR study)," Arteriosclerosis, Thrombosis, and Vascular Biology, vol. 22, no. 7, pp. 1162-1167, 2002.

[31] E. Verhoye and M. R. Langlois, "Circulating oxidized lowdensity lipoprotein: a biomarker of atherosclerosis and cardiovascular risk?" Clinical Chemistry and Laboratory Medicine, vol. 47, no. 2, pp. 128-137, 2009.

[32] K. A. Pritchard Jr., S. M. Schwarz, M. S. Medow, and M. B. Stemerman, "Effect of low-density lipoprotein on endothelial cell membrane fluidity and mononuclear cell attachment," American Journal of Physiology-Cell Physiology, vol. 260, no. 1, pp. C43-C49, 1991.

[33] D. M. Smalley, J. H.-C. Lin, M. L. Curtis, Y. Kobari, M. B. Stemerman, and K. A. Pritchard Jr., "Native LDL increases endothelial cell adhesiveness by inducing intercellular adhesion molecule-1," Arteriosclerosis, Thrombosis, and Vascular Biology, vol. 16, no. 4, pp. 585-590, 1996.

[34] J. H.-C. Lin, Y. Zhu, H. L. Liao, Y. Kobari, L. Groszek, and M. B. Stemerman, "Induction of vascular cell adhesion molecule-1 by low-density lipoprotein," Atherosclerosis, vol. 127, no. 2, pp. 185-194, 1996.

[35] C. A. Gleissner, N. Leitinger, and K. Ley, "Effects of native and modified low-density lipoproteins on monocyte recruitment in atherosclerosis," Hypertension, vol. 50, no. 2, pp. 276-283, 2007.

[36] X.-L. Tian and Y. Li, "Endothelial cell senescence and agerelated vascular diseases," Journal of Genetics and Genomics, vol. 41, no. 9, pp. 485-495, 2014.

[37] T. Tsukatani, H. Suenaga, T. Higuchi et al., "Colorimetric cell proliferation assay for microorganisms in microtiter plate using water-soluble tetrazolium salts," Journal of Microbiological Methods, vol. 75, no. 1, pp. 109-116, 2008.

[38] R. K. Gary and S. M. Kindell, "Quantitative assay of senescenceassociated $\beta$-galactosidase activity in mammalian cell extracts," Analytical Biochemistry, vol. 343, no. 2, pp. 329-334, 2005.

[39] K. Itahana, J. Campisi, and G. P. Dimri, "Methods to detect biomarkers of cellular senescence: the senescence-associated $\beta$ galactosidase assay," Methods in Molecular Biology, vol. 371, pp. 21-31, 2007.

[40] A. Krishan, "Rapid flow cytofluorometric analysis of mammalian cell cycle by propidium iodide staining," Journal of Cell Biology, vol. 66, no. 1, pp. 188-193, 1975.

[41] J. A. Royall and H. Ischiropoulos, "Evaluation of $2^{\prime}, 7^{\prime}$-dichlorofluorescin and dihydrorhodamine 123 as fluorescent probes for intracellular $\mathrm{H}_{2} \mathrm{O}_{2}$ in cultured endothelial cells," Archives of Biochemistry and Biophysics, vol. 302, no. 2, pp. 348-355, 1993.

[42] R. Colas, V. Pruneta-Deloche, M. Guichardant et al., "Increased lipid peroxidation in LDL from type-2 diabetic patients," Lipids, vol. 45 , no. 8, pp. 723-731, 2010.

[43] C.-Y. Han and Y. K. Pak, "Oxidation-dependent effects of oxidized LDL: proliferation or cell death," Experimental and Molecular Medicine, vol. 31, no. 4, pp. 165-173, 1999.

[44] S. Allen, S. Khan, Futwan-Al-Mohanna, P. Batten, and M. Yacoub, "Native low density lipoprotein-induced calcium transients trigger VCAM-1 and E-selectin expression in cultured human vascular endothelial cells," Journal of Clinical Investigation, vol. 101, no. 5, pp. 1064-1075, 1998.
[45] H. Jeon and S. C. Blacklow, "Structure and physiologic function of the low-density lipoprotein receptor," Annual Review of Biochemistry, vol. 74, pp. 535-562, 2005.

[46] I. Levitan, S. Volkov, and P. V. Subbaiah, "Oxidized LDL: diversity, patterns of recognition, and pathophysiology," Antioxidants and Redox Signaling, vol. 13, no. 1, pp. 39-75, 2010.

[47] I. Ben-Porath and R. A. Weinberg, "The signals and pathways activating cellular senescence," International Journal of Biochemistry and Cell Biology, vol. 37, no. 5, pp. 961-976, 2005.

[48] J. Campisi and F. D’Adda Di Fagagna, "Cellular senescence: when bad things happen to good cells," Nature Reviews Molecular Cell Biology, vol. 8, no. 9, pp. 729-740, 2007.

[49] P. D. Adams, "Healing and hurting: molecular mechanisms, functions, and pathologies of cellular senescence," Molecular Cell, vol. 36, no. 1, pp. 2-14, 2009.

[50] L. Vergnani, S. Hatrik, F. Ricci et al., "Effect of native and oxidized low-density lipoprotein on endothelial nitric oxide and superoxide production: key role of L-arginine availability," Circulation, vol. 101, no. 11, pp. 1261-1266, 2000.

[51] K. A. Pritchard Jr., L. Groszek, D. M. Smalley et al., "Native low-density lipoprotein increases endothelial cell nitric oxide synthase generation of superoxide anion," Circulation Research, vol. 77, no. 3, pp. 510-518, 1995.

[52] K. A. Pritchard Jr., A. W. Ackerman, J. Ou et al., "Native lowdensity lipoprotein induces endothelial nitric oxide synthase dysfunction: role of heat shock protein 90 and caveolin-1," Free Radical Biology and Medicine, vol. 33, no. 1, pp. 52-62, 2002.

[53] D. W. Stepp, J. Ou, A. W. Ackerman, S. Welak, D. Klick, and K. A. Pritchard Jr., "Native LDL and minimally oxidized LDL differentially regulate superoxide anion in vascular endothelium in situ," American Journal of Physiology-Heart and Circulatory Physiology, vol. 283, no. 2, pp. H750-H759, 2002. 


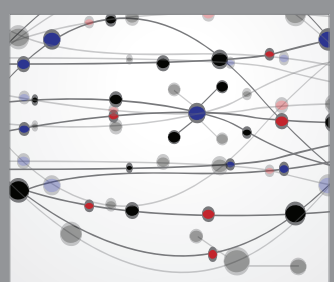

The Scientific World Journal
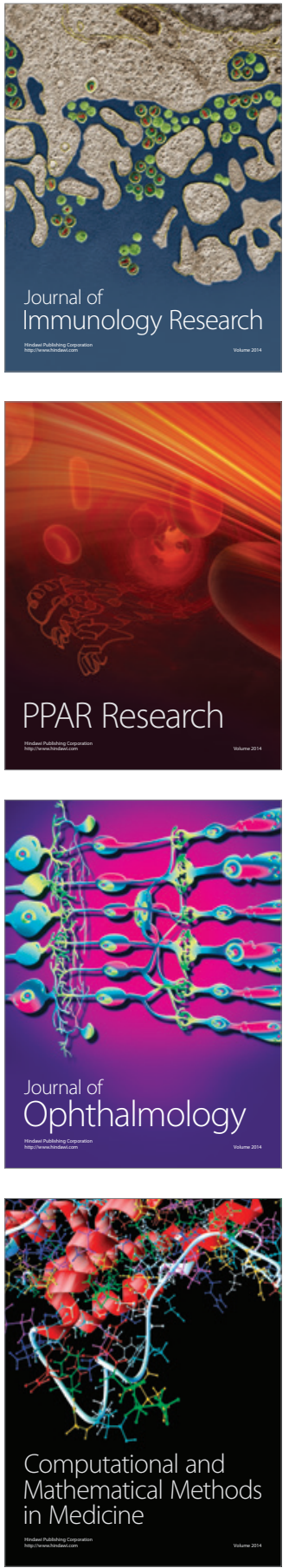

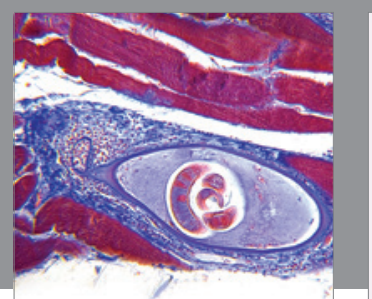

Gastroenterology Research and Practice
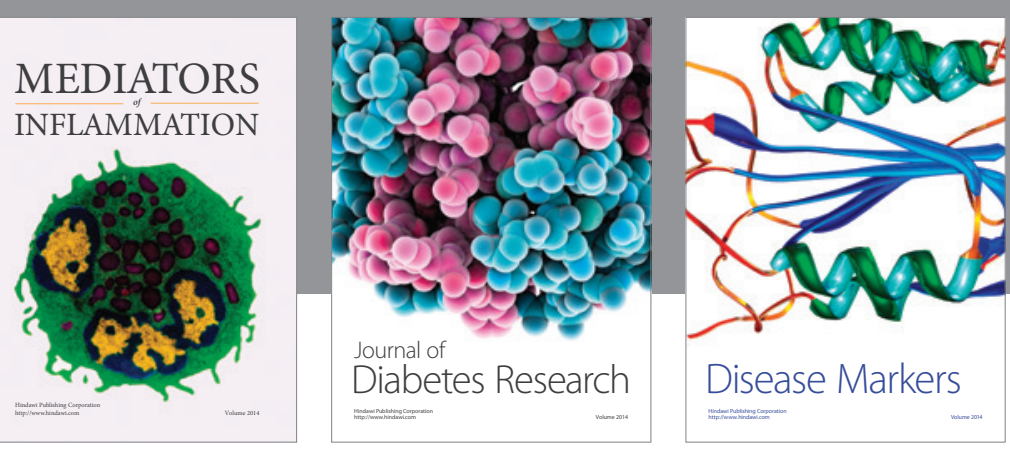

Disease Markers

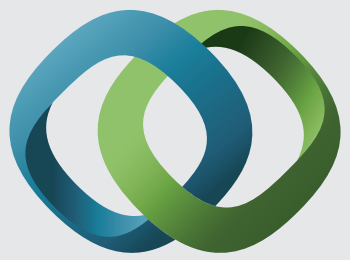

\section{Hindawi}

Submit your manuscripts at

https://www.hindawi.com
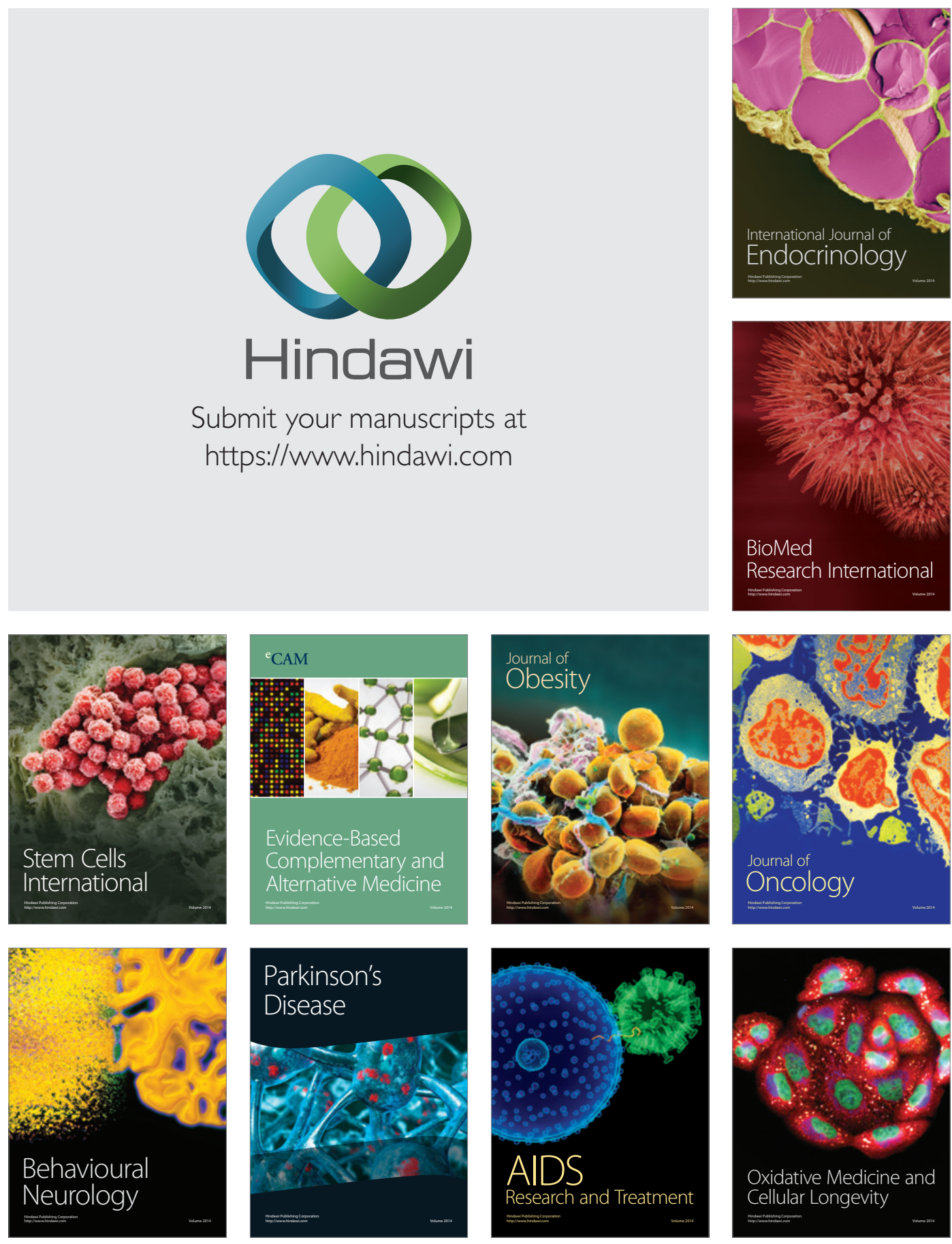